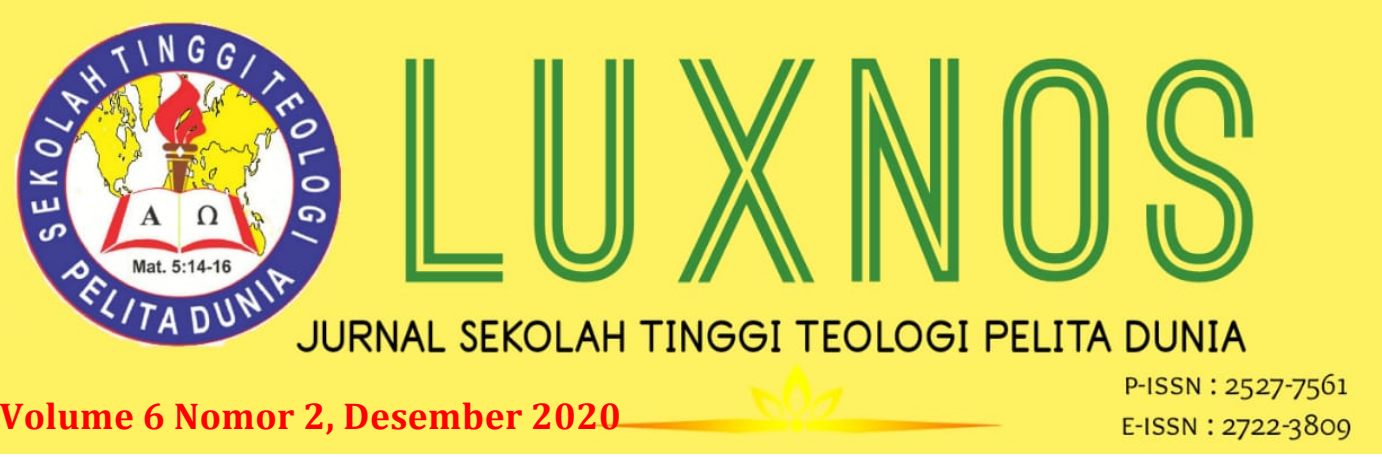

\title{
Wawasan Dunia Kristen Dan Bahasa: Kepentingan Dan Implikasinya Dalam Pemberitaan Injil Melalui Media Sosial
}

\author{
Roedy Silitonga \\ Universitas Pelita Harapan, Karawaci - Banten \\ roedy.silitonga@uph.edu
}

\begin{abstract}
This article is the result of qualitative inductive research which is descriptive analysis on "Christian Worldview and Language: Its Importance and Implications in Preaching the Gospel through Social Media." Apart from the literature study, this article is also the author's experience in using social media for evangelizing. This article concerns Christian worldview and language on the five elements and uniqueness of biblical narratives that are needed in any preaching of the Gospel on social media. This article also explains the implications of the Christian worldview and language in the preaching of the Gospel through social media today for all generations and ages.
\end{abstract}

Keywords: Christian worldview, Language, Social Media, the Gospel

\begin{abstract}
Abstrak: Artikel ini merupakan hasil penelitian induktif kualitatif yang bersifat analisis deskriptif mengenai "Wawasan Dunia Kristen dan Bahasa: Kepentingan dan Implikasinya dalam Pemberitaan Injil melalui Media Sosial." Selain studi kepustakaan, artikel ini juga merupakan pengalaman penulis dalam menggunakan media sosial sebagai sarana untuk pemberitaan Injil. Artikel ini menekankan kepentingan wawasan dunia Kristen dan bahasa pada lima elemen dan keunikan narasi-narasi Alkitab yang dibutuhkan dalam setiap pemberitaan Injil di media sosial. Artikel ini juga menjelaskan implikasi dari wawasan dunia Kristen dan bahasa dalam pemberitaan Injil melalui media sosial saat ini untuk semua generasi dan usia.
\end{abstract}

Kata Kunci: Wawasan Dunia Kristen, Bahasa, Media Sosial, Injil

\section{Pendahuluan}

Manusia adalah ciptaan Allah yang memiliki kemampuan berbahasa dengan perangkat khusus pada dirinya untuk menyampaikan pikiran, kehendak dan afeksinya secara lisan dan tulisan. Kemampuan berbahasa sudah ada di dalam diri seseorang sejak 
konsepsi ${ }^{1}$ di rahim ibu dan secara progresif terbentuk sejalan dengan perkembangan fungsi inderawi yang dikendalikan oleh otak dan pikirannya. Kemampuan itu juga mendorong dan menuntun seseorang untuk memberikan nama, definisi dan makna pada apa dan siapa saja yang dapat diserap atau diketahui olehnya. Dengan demikian terbentuklah simbol, tanda dan huruf secara bertahap yang dapat diwujudkan dalam sebuah kata, kalimat, plot cerita dan kisah-kisah untuk menjelaskan realitas hidup dan kehidupan di alam semesta ini. Proses pembentukan wawasan dunia seseorang atas realitas, ilmu pengetahuan, etika, antropologi, dan teologi dimulai dari hal-hal tersebut.

Kata-kata yang digunakan seseorang untuk berkomunikasi adalah inheren pada diri manusia sebagai pribadi, yang diungkapkannya kepada sesama manusia yang ada di dalam maupun di luar komunitasnya. Dengan demikian, setiap orang dapat secara bebas mendefinisikan realitas yang ada di bumi dan alam semesta melalui kemampuan bahasanya. Kemampuan bahasa seseorang dapat dibentuk, dilatih dan dikembangkan mulai dari dalam lingkungan keluarga, kelompok sosial, masyarakat, etnis dan bangsa. Kemampuan bahasa tersebut dapat diketahui dan dikenal oleh orang lain, serta saling mempengaruhi dalam perkembangan kemajuan peradaban manusia di bumi ini.

Sejalan dengan kemampuan manusia itu, bahasa pada dirinya terus-menerus mengalami perkembangan bersamaan dengan meningkatnya pengetahuan pra teoritis, teoritis dan teknologi yang digunakan pada zamannya. Dalam konteks seperti itu di zaman digital ini, persepsi, motivasi dan tujuan dari peristiwa-peristiwa komunikasi yang dialami manusia secara individu dan komunitas. Hal itu dapat memberikan arah dan struktur pada pesan yang diterima dan yang disampaikan dari dan ke pihak lain. Setiap orang memiliki kesempatan yang sama untuk berbicara dan menyatakan pikirannya berdasarkan wawasan dunianya dengan pihak lain. Menurut Kevin S. Trowbridge, "Communication permeates every facet of who we are and what we do (Faith and Learning, 2012:323)." Selain itu, setiap orang secara aktif dapat dan mampu mendefinisikan, memberi makna, memperdalam pengertian dan merefleksikan realitas masyarakat dan budaya tertentu berdasarkan pada wawasan dunia yang dipelajari atau dihidupinya sebagai suatu sistem kehidupan di zaman digital ini melalui media sosial.

Kemampuan dan kesempatan tersebut sangat bermanfaat untuk menggali temukan potensi yang ada pada seseorang melalui bahasa sehingga terjadi sebuah proses tumbuh kembang dari ilmu pengetahuan, pengalaman dan intuisinya. Akan tetapi, otoritas berkomunikasi tersebut akan berada pada batasan moral yang diterima dan diakui oleh komunitasnya atau lingkungannya. Dengan demikian, wawasan dunia dan bahasa seseorang akan berimplikasi langsung, baik pada waktu menyampaikan pesan, informasi dan fakta kepada pihak lain, maupun pada saat ia menanggapi realitas atau peristiwa yang dialaminya. Wawasan dunia yang benar akan memberikan fondasi,

1 https://kbbi.web.id/konsepsi: percampuran antara inti sel jantan dan inti sel betina; pembuahan benih. 
arah dan struktur melalui penggunaan bahasa yang benar dan baik yang berimplikasi pada berita yang disampaikan kepada publik melalui media sosial saat ini.

Kemampuan bahasa seseorang akan dipengaruhi dan mempengaruhi pengertian dan isi setiap elemen dari wawasan dunianya. Sebab bahasa dapat mewakili pemikiran seseorang dalam kelompok atau komunitasnya. Menurut Jonter Pandapotan Sitorus, "Cara pandang seseorang terhadap bahasa bergantung pada pengetahuan manusia itu sendiri. Dengan kata lain, unsur utama yang digunakan dalam memahami bahasa, berpusat pada diri manusia itu sendiri sehingga manusia selalu mencari jawaban dari keberadaan bahasa itu di dalam hidupnya."2 Karena itu bagi orang Kristen, sangat penting kemampuan mengenal wawasan dunia Kristen dan wawasan dunia orang lain dengan benar untuk mengevaluasi dengan benar, obyektif dan logis tentang fondasi, arah dan struktur dari setiap kata dan kalimat yang dibaca atau didengar di media sosial.

Ketika konten di media sosial ditulis atau diunggah oleh seseorang secara publik, maka sangat penting untuk menyadari apakah isi dari konten tersebut berkualitas, apakah sesuai dengan wawasan dunia Kristen yang berbasiskan pengajaran Alkitab atau bertentangan dengan kebenaran Allah atau apakah ada yang dapat dipelajari secara umum berguna bagi sesama manusia saat ini? sebab sebuh konten yang dinyatakan ke publik dengan bahasa (kata, kalimat, gambar, video, dll.) merupakan hasil dari proses pemikiran yang sudah dirumuskan dan disesuaikan dengan konteks pembaca/pendengar di media sosial.

Wawasan dunia Kristen merupakan fondasi, arah dan struktur bagi orang Kristen untuk menyampaikan pesan kebenaran, keadilan dan kesucian yang bersifat ontologis, normatif, dan praktis. Orang Kristen dapat menjelaskan realitas, ilmu pengetahuan, etika, kemanusiaan dan teologi yang berbasiskan pada ajaran Alkitab. Prinsip-prinsp kebenaran Allah di dalam Alkitab dituliskan dalam kisah-kisah yang agung, mulai dari asal-mula penciptaan, kejatuhan, penebusan, sampai kepada penciptaan ulang. Berdasarkan pada pemikiran tersebut, tulisan ini menekankan pada kepentingan wawasan dunia Kristen yang diajarkan dan dijelaskan di media sosial dengan menggunakan bahasa yang baik dan benar kepada publik, khususnya berkaitan dengan pemberitaan Injil Yesus Kristus.

Implikasi yang diharapkan dari tulisan ini ialah pembaca dan pengguna media sosial dapat mengevaluasi kualitas dan kuantitas berita serta konten yang diunggah di media sosial seperti facebook, Youtube, dan Instragram, apakah isinya sungguh-sungguh berdasarkan pada wawasan dunia Kristen yang komprehensif? Apakah setiap orang Kristen sungguh-sungguh menyadari kepentingan wawasan dunia Kristen pada waktu menggunakan bahasa di media sosial dengan tujuan penginjilan bagi segala bangsa

2 Jonter Pandapotan Sitorus, Wawasan Dunia Kristen dan Wawasan Dunia Ilmu Pengetahuan terhadap Bahasa (Malang: Evernity, 2018), 29. 
sudah dilakukan secara efektif? Mengapa penting bagi orang Kristen menggunakan bahasa yang baik, benar, adil dan suci pada waktu menyampaikan berita Injil di media sosial? Bagaimana orang Kristen memilih kata dan menyusun kalimat untuk menjelaskan Injil berdasarkan pada wawasan dunia Kristen yang berbasiskan ajaran Alkitab melalui berbagai sarana media sosial?

\section{Metode Penelitian}

Metode penelitian yang digunakan dalam tulisan artikel ini ialah metode penelitian induktif dengan pendekatan studi kepustakaan. Dalam studi kepustakaan itu, penulis mengumpulkan informasi, data, dan fakta, lalu menyusun, mengklasifikasi dan menginterpretasinya sebagai landasan prinsip dan konsep sehingga arah dan struktur tulisan berada dalam konteks kekinian dan relevan bagi pembacanya. Menurut Nancy Jean Vyhmeister, "Descriptive research usually studies a situation at a given moment in time. Analysys is examing the evidence by piece. A specialized type of descriptive research studies a person, case, or situation over time". ${ }^{3}$ Selain itu, penulis juga menggunakan metode penelitian kualitatif deskriptif untuk menganalisa topik Wawasan Dunia Kristen dan Bahasa dengan berbagai sumber buku, artikel di jurnal dan realitas sosial budaya saat ini sehingga secara sistematis dan bersifat praktis.

\section{Hasil dan Pembahasan \\ Kepentingan Wawasan Dunia Kristen}

Dalam konteks saat ini, orang Kristen sudah menerima warisan pengajaran yang bersumber dari Alkitab dan diwujudkan melalui dogma gereja, teologi biblika, teologi sistematika dan teologi praktika. Warisan pengajaran itu dituliskan dan diajarkan kembali oleh gereja melalui bahasa dalam bentuk buku, jurnal, video dan media sosial. Sejalan dengan hal itu, orang Kristen juga sudah menerima, mengikuti dan meneruskan berbagai tradisi gereja yang berkaitan dengan ibadah, pelayanan dan pengakuan iman yang hadir dalam sejarah gereja dan meruntuhkan segala pengajaran yang tidak benar. Tradisi gereja yang teruji kebenarannya dan relevan itu telah dinyatakan kepada jemaat melalui bahasa lokal/nasional dimana jemaat berada saat ini.

Karena kepentingan seluruh warisan rohani tersebut di atas sebagai fondasi, struktur dan arah bagi setiap orang Kristen sepanjang abad untuk memuliakan Allah dan menikmati-Nya sehingga setiap orang Kristen mempelajari dengan benar dan mampu mengomunikasikan serta menerapkan dengan tepat sesuai konteks kehidupannya. Seluruh warisan pengajaran dan tradisi gereja dapat diajarkan dan diproklamasikan dari satu generasi ke generasi melalui bahasa jemaat lokal dengan baik dan benar di dalam komunitas keluarga, gereja, dan sekolah/perguruan tinggi. Dengan

${ }^{3}$ Nancy Jean Vyhmeister, Quality Research Papers: for students of religions and theology (Grand Rapids, Michigan: Zondervan, 2001), 127. 
demikian warisan iman tersebut dipertahankan dan dikembangkan setiap orang Kristen sebagai prinsip dan sistem kehidupan yang relevan dengan tantangan dan kebutuhan zaman.

Keseluruhan warisan iman itu telah menjadi suatu konstruksi dan prinsip dasar dari wawasan dunia bagi orang Kristen saat ini. Awalnya konsep wawasan dunia "Weltanschaung" dipopulerkan oleh Imanuel Kant, lalu para teolog juga menggunakan istilah dan konsep yang sama untuk menjelaskan perspektif yang segar mengenai hakikat segala sesuatu, dimensi kosmis dan aplikasi iman yang universal. ${ }^{4}$ Wawasan dunia Kristen ini sudah hadir dalam sejarah perkembangan gereja sejak abad pertama, diformulasikan sejak reformasi gereja pada abad ke-16 sebagai sistem kehidupan bagi orang Kristen. Gereja sedang berhadapan langsungdengan berbagai wawasan dunia dalam peperangan prinsip. Formulasi Wawasan Dunia Kristen dipertegas oleh James Orr yang menekan bahwa: "Orang yang percaya kepada Yesus sebagai Anak Allah dengan segenap hatinya akan setia untuk hal-hal lainnya. Dia akan setia pada wawasan tentang Allah, manusia, dosa, penebusan, takdir manusia yang ada di dalam Kekristenan."5 Selanjutnya Abraham Kuyper merumuskan Wawasan Dunia Kristen itu sebagai Sistem Kehidupan dalam bukunya Lecturers of Calvinism pada tahun 1889. Pernyataan yang terkenal dari Abraham Kuyper ialah "Tidak ada satu inchi pun di dalam seluruh wilayah dari keberadaan manusia dimana Kristus, yang berdaulat atas segala sesuatu dan Dia tidak berteriak, "ini milik-Ku." Dengan demikian kepentingan dan implikasi Wawasan Dunia Kristen dalam pemberitaan Injil merupakan keharusan bagi orang Kristenyang berbasiskan Alkitab, berpusatkan Kristus dan komprehensif dalam seluruh elemen.

Dalam konteks saat ini, peperangan prinsip tidak lagi hanya di dalam kalangan akademis dan rohaniawan saja, tetapi peperangan prinsip wawasan dunia sudah mendunia pada zaman digital melalui media sosial. Orang Kristen tidak dapat menghindari kenyataan bahwa setiap hari di media sosial ditampilkan berbagai wawasan dunia yang bertentangan dengan wawasan dunia Kristen. Misalnya, pengguna Youtube di seluruh dunia lebih dari 2 miliar pengguna. ${ }^{6}$ Tanggapan atas kondisi saat ini, orang Kristen seharusnya sudah memiliki wawasan dunia Kristen yang utuh dan lengkap sebagai suatu sistem kehidupan untuk menghadapi berbagai prinsip dari wawasan dunia lainnya. Sebab tanpa pemahaman dan pendalaman yang komprehensif tentang wawasan dunia Kristen, seseorang akan mengalami kesulitan dalam menentukan sikap dan tindakan yang benar, adil dan suci. Karena media sosial bukan sekedar informasi, data dan hiburan tetapi sudah pada tahap sebagai salah satu cara

4 David K. Naugle, Wawasan Dunia Sejarah Sebuah Konsep (Sebuah Pandangan Kristen (Surabaya: Momentum, 2010), 6.

${ }^{5}$ Naugle, Wawasan Dunia, 10.

6 https://www.youtube.com/intl/id/about/press/ diakses hari Minggu, 15 November 2020, pk.21:21. 
untuk mencemarkan prinsip kehidupan yang seharusnya orang Kristen lakukan di bumi ini.

\section{Kepentingan Bahasa dalam Wawasan Dunia Kristen}

Bahasa merupakan hasil dari pengetahuan dan pengalaman manusia di bumi ini yang berkembang dari simbol, perkataan lisan, tulisan, sampai ke dalam pemanfaatan teknologi digital untuk berkomunikasi dan berinteraksi antar sesama manusia secara individu dan kelompok dalam konteks zaman dan budaya. Bahasa manusia semakin kompleks, tidak hanya mengungkapkan suara yang memiliki arti yang bersifat informatif tetapi juga berdampak pada kehidupan manusia serta pembentukan wawasan dunia seseorang. Selain itu, bahasa juga sebagai bentuk dan sarana dari perwujudan pemikiran peradaban manusia sepanjang zaman yang dapat di tangkap secara inderawi, dipelajari dan diwariskan dari generasi ke generasi.

Dalam keadaan seperti itu, wawasan dunia Kristen hadir sebagai prinsip untuk mempengaruhi dan memberikan arah sejarah umat manusia melalui bahasa manusia dengan sistem kehidupan yang bersumber dari ajaran Alkitab. Dalam konteks zaman digital ini, orang Kristen harus lebih produktif dan kreatif menggunakan media sosial sebagai sarana mengajarkan prinsip wawasan dunia Kristen dengan utuh dan lengkap, khususnya dalam memberitakan Injil Yesus Kristus. Tentulah upaya itu dilakukan dengan menggunakan gaya bahasa yang kontekstual dan relevan sehingga kebenaran Allah dapat diketahui dan dikenal dengan baik. Upaya ini juga diarahkan untuk menebus bahasa yang ada di media sosial dengan mentransformasi kualitas isi tulisan, gambar dan video yang disajikan dan diunggah, khususnya dalam memproklamasikan Injil Yesus Kristus.

Era digital merupakan suatu masa di mana setiap orang bebas memproyeksikan pikirannya (imajinasinya) dengan bahasa yang ada pada dirinya untuk mengungkapkan realitas, ilmu pengetahuan, etika dan kemanusiaan ke publik. Dalam hal ini, tentulah orang Kristen dapat tampil di publik melalui media sosial dalam peperangan prinsip kehidupan. Menurut Gordon H. Clark "Kekristenan adalah suatu wawasan yang komprehensif mengenai segala sesuatu; Kekristenan melihat dunia, baik material maupun spiritual sebagai sebuah sistem yang tertata. ${ }^{7}$ Sistem kehidupan yang sistematis dan praktis itu dapat disaksikan dari seluruh kebenaran Allah yang tertulis dan yang ada pada karya-Nya kepada para pengguna media sosial.

Bagi orang Kristen, firman Tuhan bermanfaat untuk mengajar, menyatakan kesalahan, memperbaiki kelakukan dan mendidik orang dalam kebenaran (2 Tim.3:16). Keseluruhan manfaat firman Tuhan dapat nyatakan ke publik melalui media sosial untuk diketahui dan dikenal. Pengguna media sosial itu akan mengetahui dan mengerti

\footnotetext{
${ }^{7}$ Naugle, Wawasan Dunia, 17.
} 
prinsip wawasan dunia Kristen bersumber dari firman Tuhan yang bermanfaat tersebut. Karena itu, penulis berharap agar setiap orang Kristen dapat menggunakan media sosial lebih produktif dan kreatif untuk mengabarkan Injil Yesus Kristus. Sebab itu kepentingan penggunaan bahasa secara kontekstual, relevan dan praktis dapat diatur dan ditata ulang agar kata dan kalimat yang dibicarakan atau dituliskan di media sosial berdasarkan pada wawasan dunia Kristen yang komprehensif.

\section{Bahasa dalam Lima Elemen Wawasan Dunia Kristen}

Bahasa dapat dipelajari dan diselidiki melalui lima elemen wawasan dunia Kristen yaitu: metafisika, epistemologi, etika, antropologi dan teologi. Kelima elemen itu merupakan satu kesatuan yang tidak terpisahkan, tetapi dapat dibedakan satu dengan yang lainnya. Tujuan penyelidikan dan pemahaman ini agar orang Kristen mengetahui kepentingan wawasan dunia Kristen dan bahasa untuk melaksanakan kehendak Allah dan memproklamasikan Injil melalui media sosial untuk berperang dengan berbagai wawasan dunia yang sedang melawan kebenaran Allah.

Dalam elemen metafisika, keberadaan segala sesuatu adalah ciptaan Allah yang menciptakan dari tidak ada menjadi ada. Allah menciptakan langit bumi dan segala isinya dengan firman-Nya melalui Logos di dalam kuasa dan naungan Roh-Nya. Demikian juga, keberadaan bahasa merupakan ciptaan Allah yang ada sejak awal penciptaan manusia di bumi ini. Keberadaan bahasa manusia sejak Adam sampai saat ini telah mengalami perkembangan keberagaman bentuk, seperti: bahasa lisan, tulisan, simbol dan gambar yang dituturkan dan dipertahankan oleh ribuan suku bangsa di seluruh dunia. Sebab pada dasarnya Allah menciptakan potensi keberagaman bahasa dan keunikannya pada umat manusia. Karena itu diketahui bahwa di setiap etnis dan bangsa ada bahasanya masing-masing yang khusus dan unik. Sebab itu berkaitan dengan pemberitaan Injil ke segala bangsa, maka kebutuhan akan penerjemahan bahasa lokal semakin penting khususnya dalam penerjemahan Alkitab. Sementara itu para pengguna media sosial pun semakin beragam suku bangsa dan bahasa yang digunakannya. Inilah saatnya, setiap orang Kristen, di suku bangsanya atau di negaranya dapat memanfaatkan media sosial untuk memberitakan Injil lebih leluasa dengan menggunakan bahasa lokal atau bahasa nasional. Misalnya, di Indonesia, orang Kristen dapat menggunakan bahasa Indonesia untuk menyampaikan Berita Injil melalui media sosial. Kendati pun di negara Indonesia terdapat ratusan suku bangsa dan ratusan bahasa yang berbeda-beda.

Alkitab menyatakan dan menjelaskan hadirnya keragaman bahasa dan asal usulnya (Kej. 10). Kendatipun, tidak ada seorang pun yang dapat mengetahui dengan tepat kapan terbentuknya ribuan bahasa yang digunakan manusia sampai saat ini. Menurut Jonter Pandapotan Sitorus, "para ahli sudah mencoba melakukan penyelidikan 
asal mula bahasa, baik melalui filologi maupun antropologi."8 Akan tetapi, manusia tetap gagal untuk mengetahui asal usul eksistensi bahasa, kecuali kembali kepada apa yang sudah dinyatakan Allah melalui Alkitab. Hingga saat ini, bahasa masih terus berkembang dan semakin limpah perbendaharaan kata seiring perkembangan ilmu pengetahuan dan kebutuhan akan penamaan dan pemaknaan atas fenomena, peristiwa, benda dan lain sebagainya yang ada di alam semesta ini. Berdasarkan keberadaan tersebut, pemberitaan Injil melalui media sosial tetaplah harus berada di dalam fondasi, arah dan struktur dari wawasan dunia Kristen. Hal ini penting agar isi berita Injil tidak akan lagi mengalami perubahan makna dan tujuan yang sesungguhnya. Selain itu, implikasinya juga bagi pengguna media sosial dari generasi muda untuk tetap mengetahui, mengenal dan mengerti Injil Yesus Kristus dengan baik dan benar.

Dalam elemen epistemologi, secara potensi dan keunikannya manusia diciptakan Allah sebagai pribadi yang berakal budi, mampu berpikir dan memahami realitas, baik secara inderawi maupun kejiwaan. Pengetahuan dasar manusia sudah ada pada dirinya, berkembang sejak lahir, hadir di dalam keluarganya, lingkungannya dan masyarakatnya. Selanjutnya, pengetahuan dan pengalaman itu terus-menerus bertumbuh dan bermanfaat setelah disistematiskan dan diajarkan di sekolah dan kampus sehingga menghasilkan berbagai disiplin ilmu dan teknologi yang berguna bagi umat manusia untuk mengelola bumi dan segala isinya.

Pengetahuan akan bahasa ini dapat diwariskan atau diajarkan secara bertahap di dalam dan melalui keluarga, sekolah, lembaga keagamaan, pekerjaan, dan kelompok masyarakat. Selain itu, keseluruhan dari pengetahuan dan pengalaman berbahasa ini dapat diajarkan dan dikembangkan manusia dalam berbagai tulisan sepanjang sejarah, termasuk melalui media sosial, misalnya: Facebook, Youtube, Instagram, Whatsapp dan LINE yang sudah digunakan oleh berbagai generasi dan lapisan umur. Saat ini, media sosial dapat dijadikan tools untuk belajar dan mengajarkan berbagai ilmu pengetahuan, pengalaman, dan intuisi secara sistematis. Hanya saja orang Kristen wajib mengisi konten di media sosial dengan prinsip Wawasan Dunia Kristen yang relevan dan yang dapat langsung diterapkan oleh para pengguna media sosial itu.

Manusia akan saling mempertajam sesamanya dalam meningkatkan kemajuan pengetahuan dan teknologi melalui berbagai bentuk atau model berbahasa, melalui kata, gambar, peta atau apa saja yang dapat ditangkap oleh inderawi manusia. Dengan demikian informasi, data dan pengetahuan akan realitas dan penemuan itu dapat disampaikan secara lengkap dan utuh. Manusia tidak hanya mendengar, melihat dan merasakan apa yang ada tetapi manusia juga dapat mengerti maksud dan tujuan dari kata, simbol dan gambar yang disampaikannya. Setiap orang memiliki kapasitas berpikir untuk menyadari dan berinteraksi dengan pikirannya sendiri serta realitas yang berada

8 J.P. Sitorus, Bahasa, 30. 
di luar dirinya sebagai bagian dari hasil penyelidikan, analisis dan evaluasi terhadap berbagai ilmu pengetahuan dan pengalamannya. Dalam kondisi seperti itu, pengetahuan tersebut diuji kebenarannya secara korespondensi, koherensi dan pragmatis. Pengetahuan yang benar seharusnya bersifat universal dan tidak kontradiksi, relevan dan dibutuhkan setiap orang di bumi ini. Dalam hal ini, media sosial dapat dimanfaatkan untuk mengembangkan dan memperbarui berbagai pengetahuan, pengalaman dan intuisi pada penggunanya.

Alkitab menyatakan dengan jelas bahwa Adam memberikan nama kepada tiaptiap mahluk hidup dan menjelaskan arti kata perempuan (Kej.2: 19, 23). Demikian juga keturunan Nuh telah mengembangkan beraneka ragam bahasa untuk keturunannya sendiri-sendiri berdasarkan tempatnya dan konteks kehidupan mereka (Kej.10-11). Alkitab telah memberikan pengetahuan mendasar dari adanya bahasa yang digunakan manusia, yang bermanfaat secara individu dan kelompok untuk mengembangkan kebudayaan dan peradaban melalui pendidikan di dalam keluarga, sekolah atau kampus dan di tempat berkarya. Manusia sebagai makhluk yang memiliki keunggulan berbahasa yang mewakili eksistensinya di bumi ini dan yang akan datang. Tidak ada seorang manusia yang tidak memiliki bahasa secara lisan atau tertulis. Keadaan seperti itulah yang mendorong setiap orang Kristen untuk berupaya memberitakan Injil melalui berbagai bahasa yang ada dan dimengerti, khususnya pada zaman digital ini melalui media sosial.

Pengetahuan bahasa dari warisan generasi sebelumnya, pengalaman diri, serta penemuan pengetahuan telah memberikan gambaran dan manfaat yang nyata bahwa bahasa merupakan buah peradaban manusia yang sentral dan bernilai. Bagi orang Kristen, melalui bahasa manusia dapat mengetahui dan mengenal ciptaan Allah serta mampu mencapai pengetahuan tentang Allah dan pengenalan akan diri-Nya. Selain itu, orang Kristen terus-menerus berjuang untuk melakukan pembaruan dalam pemakaian bahasa secara lisan dan tulisan, baik dalam percakapan informal dan formal untuk menyatakan segala kebenaran pengetahuan akan alam semesta dan segala isinya secara khusus di dalam mengenal Allah dengan benar. Media sosial dapat dimanfaatkan secara efektif untuk mengembangkan metode dan model pemberitaan Injil tanpa mengurangi esensi Injil yang diajarkan Alkitab. Para pengguna media sosial dapat lebih tertarik dengan konten yang kreatif dengan pesan yang tetap bersumber dari ajaran Alkitab.

Sejalan dengan upaya melaksanakan mandat Injil menurut Matius 28:19-20, murid-murid Kristus seharusnya sudah mempelajari bahasa lokal dari penduduk sebuah etnis atau sub etnis yang akan mendengarkan Injil Yesus Kristus. Sekalipun proses belajar mengetahui dan mengenal bahasa atau translasi Alkitab membutuhkan waktu puluhan tahun, namun tujuan yang akan dicapai dari penginjilan akan lebih optimal. Menurut F. Budi Hardiman dalam bukunya Seni Memahami (2015) menjelaskan, "Di dalam kegiatan menerjemahkan sebuah teks berbahasa asing ke dalam bahasa kita 
sendiri, kita harus terlebih dahulu memahami dan kemudian mencoba mengartikulasikan pemahaman kita kepada orang lain melalui pilihan kata dan rangkaian terjemahan kita." ${ }^{\prime 9}$ Dengan demikian, Berita Injil dapat diproklamasikan lebih tepat dan diterima pendengar lokal.

Dalam konteks saat ini, orang Kristen sudah dapat membaca Alkitab dalam berbagai versi terjemahan bahasa di dunia ini, walaupun tidak semua orang Kristen dapat mengomunikasikan Alkitab dalam beragam terjemahan kepada para pendengarnya dengan baik. Akan tetapi, hal tersebut telah membuka peluang dan memberanikan orang Kristen untuk memanfaatkan segala terjemahan Alkitab dengan baik. Dengan demikian, orang Kristen penting terus-menerus mempelajari berbagai perkembangan bahasa agar kehendak Allah dapat dipublikasikan ke seluruh dunia untuk menjadikan segala bangsa murid Kristus. Dalam konteks saat ini, media sosial (facebook, instragram, Youtube, dll.) menjadi sarana penting dalam mengajarkan kepentingan wawasan dunia Kristen untuk pemberitaan Injil secara publik dengan bahasa yang dapat dimengerti oleh para pengguna dari konten atau video yang diunggah. Perjuangan iman seperti itu sangat penting untuk dikobarkan dengan sungguh-sungguh melalui media sosial, sebab di media sosial telah banyak beredar konten video atau tulisan yang bertentangan dengan ajaran Alkitab yang menyesatkan publik. Orang Kristen seharusnya berani berperang dan maju untuk mempertahankan wawasan dunia Kristen melalui media sosial agar para pengguna dari berbagai suku bangsa dan bahasa mendengarkan Injil Yesus Kristus.

Dalam elemen etika, Allah adalah dasar dari hukum moral yang seharusnya menguasai perilaku manusia dan menyebabkan adanya tatanan di dalam manusia. ${ }^{10}$ Allah adalah satu-satunya sumber moral bagi kehidupan manusia di bumi, karena di dalam moral Allah yang sempurna dan kekal itu ada kebaikan, keadilan dan kesucian. Yakobus mengajarkan prinsip moral tersebut kepada orang Kristen di sepanjang zaman untuk berhati-hati menggunakan lidah (kata-kata) kepada siapa pun, khususnya kepada Allah (Yak.3:1-12). Penulis yakin dan sadar bahwa orang-orang Kristen wajib menjaga kesucian hidupnya melalui kata-kata yang diucapkan, ditulis dan disampaikan melalui media sosial sehingga tidak ada kata-kata yang sia-sia, cemar dan menajiskan hati nurani.

Orang Kristen tidak lagi menggunakan kata-kata yang sia-sia, cemar dan menajiskan kualitas dalam menyampaikan berita Injil, seperti yang dilakukan oleh orang-orang dunia di berbagai media sosial saat ini. Oleh karena itu, kita berada di zaman online di mana bahasa yang sudah dituliskan dan diucapkan di media sosial akan melintasi ruang dan waktu. Sebab jejak digital tidak terhapus untuk waktu yang begitu

${ }^{9}$ F. Budi Hardiman, Seni Memahami: Hermeneutik dari Schleimacher sampai Derida (Yogyakarta: Kanisius, 2015), 11-12.

10 Ronald H. Nash, Iman dan Akal Budi (Jakarta: Momentum, 2001), 59. 
lama. Saat ini di seluruh dunia, media sosial sudah digunakan oleh ratusan juta penduduk dunia dan menjadi bagian dari peradaban manusia. Namun orang Kristen perlu memperhatikan tanggapan dari Samuel James sebagai berikut:

There was a time, not too long ago, when being online was universally considered an activity, something that people did for entertainment or business. Now it arguably would be more accurate to refer to the experience of the Internet as an existence. Many, perhaps most of us, are connected to the Internet so frequently, and so automatically, that we have a hard time imagining even a week without any online presence. We work, watch, debate, learn, reveal, celebrate, mourn, and confess online. And as we do this, we embodied souls are receiving a digital imprint. ${ }^{11}$

Dengan demikian, zaman ini merupakan kesempatan untuk pemberitaan Injil kepada segala bangsa di seluruh dunia tanpa batasan generasi, dengan menggunakan bahasa yang baik dan benar serta memiliki kualitas yang kudus, agung dan mulia.

Dalam elemen antropologi, manusia adalah ciptaan Allah menurut gambar dan rupa Allah. Manusia, laki-laki dan perempuan, setara dan se-hakikat sebagai gambar dan rupa Allah, mewakili Allah di bumi dan menyerupai-Nya dalam pengetahuan yang benar, keadilan yang benar, dan kekudusan. Namun, kedua jenis manusia ini berbeda menurut urutan penciptaan dan tanggung jawab dalam konteks tatanan keluarga, masyarakat, gereja, bangsa dan negara. Adam diciptakan terlebih dahulu, kemudian Hawa dari tulang rusuknya. Laki-laki sebagai kepala keluarga; perempuan adalah ibu, yang mendampingi suaminya dalam keluarganya. Manusia pada dirinya merupakan mahluk yang paradoks, pada dirinya secara individu dan dalam hubungannya dengan individu lainnya.

Paradoks kesetaraan dan ordo di setiap tatanan kelembagaan manusia secara individu dapat terlihat dan terwujud melalui tutur kata dan pilihan kata yang dipakai seseorang dalam berbicara dan menempatkan dirinya. Pengaturan dan ketentuan dalam berinteraksi dan bersosialisasi bagi laki-laki dan perempuan di setiap kelembagaan selalu menampilkan tutur kata dan gaya bahasa yang indah, agung dan bermartabat. Sistem bahasa dalam setiap suku bangsa memiliki keunikan dan makna untuk mendeskripsikan hubungan antar individu, antar keluarga, antar kelompok, dan antar komunitas dalam suatu suku bangsa. Dalam keadaan seperti itu, orang Kristen memiliki kesempatan yang bernilai mengajarkan Injil Kristus pada setiap kelembagaan manusia. Sementara dalam konteks saat ini, media sosial menerobos dan mencairkan situasi kekakuan di setiap kelembagaan manusia itu dalam batas-batas yang wajar. Dengan

11 Samuel James (2019), Constantly (Dis)connected: How Online Habits Form Us, diakses dari https://www.desiringgod.org/articles/constantly-disconnected, pada hari Senin, tanggal 07 September 2020, pukul 21:44. 
demikian orang Kristen, laki-laki dan perempuan lebih bebas memberitakan Injil tanpa sekat-sekat primordial suku bangsanya.

Keberadaan orang Kristen selalu identik dengan apa yang diucapkannya kepada diri sendiri, sesama, lingkungan dan terutama kepada Allah. Orang Kristen berdoa kepada Allah dan memuji-Nya dengan menggunakan kata-katanya sendiri. Allah menyatakan diri-Nya secara pribadi kepada umat-Nya melalui firman-Nya dengan bahasa manusia. Bahasa penting dalam hubungan antar sesama manusia dan hubungan individu dan komunitas dengan Allah. Dalam wawasan dunia Kristen, manusia adalah mahluk bahasa, diciptakan Allah dengan firman-Nya dan mampu memproduksi katakata pada dirinya sendiri. Ketika orang Kristen berbicara kepada sesama, ia akan berusaha menegaskan akan adanya gambar rupa Allah yang disandang setiap orang. Ia berusaha menghargai dan menghormati sesama sekalipun berbeda suku, bangsa dan bahasanya. Sebab itu upaya orang Kristen mengajarkan pemahaman tentang gambar rupa Allah yang sudah rusak karena dosa dan membutuhkan penebusan Kristus secara langsung kepada banyak orang merupakan tindakan natural dan spiritual. Hal itu dapat dilakukan melalui media sosial dengan lebih leluasa, universal, masif, dan berdampak.

Dalam elemen teologi, bahasa diciptakan Allah pada waktu Allah menciptakan manusia sebagai gambar dan rupa-Nya. Menurut Ronald Nash, "wawasan dunia Kristen merupakan sebuah teistik dalam arti wawasan dunia ini percaya akan adanya satu Allah yang penuh dengan kuasa dan berpribadi."12 Orang Kristen percaya Allah yang Esa, Tiga Pribadi yang kekal, yaitu: Bapa, Anak dan Roh Kudus. Ketiga-Nya yang Esa berfirman dan menyatakan firman-Nya. Firman Allah ditulis, diajarkan, dan diteruskan dari generasi ke generasi dengan kekuatan dan kuasa Roh Kudus agar mengenal Allah melalui Tuhan Yesus Kristus. Bahasa berfungsi menjembatani antara firman Tuhan dan manusia agar umat pilihan memiliki kebenaran Allah dan bersaksi tentang diri-Nya kepada sesama.

Firman Tuhan merupakan bahasa tulisan yang diwahyukan Allah dan dimengerti umat-Nya. Karena Allah menciptakan manusia memiliki potensi dan kapasitas untuk mengenal diri-Nya. Tanpa firman Tuhan, manusia tidak mungkin mengenal Allah secara pribadi dan tidak mengenal keselamatan hidup kekal melalui Tuhan Yesus Kristus. Orang Kristen wajib membaca, mempelajari dan mempraktikkan firman Tuhan. Sejalan dengan hal itu, umat Allah dipimpin Roh Kudus melalui firman Tuhan untuk mengenal Sang Firman secara langsung. Sebab itu penting dan perlu belajar firman Tuhan dengan benar agar konten yang disebarluaskan melalui media sosial sungguh-sungguh berkualitas dan menuntun pengguna menaati Allah. Sebab ada juga yang sembarangan menafsirkan firman Tuhan dan mengajarkan kepada banyak

12 Nash, Iman, 51. 
orang melalui media sosial, tetapi isi ajarannya bertentangan dengan seluruh ajaran Alkitab.

Orang Kristen belajar firman Tuhan sebagai fondasi berteologi, tidak lagi hanya di kelas dan perpustakaan. Setiap orang dapat belajar firman Tuhan dari berbagai sumber yang ada di media sosial secara langsung dan rekaman dari berbagai ahli yang berkualitas secara akademis, rohani dan teladan dalam kehidupan Kristen. Karena media sosial bersifat bebas dan terkadang isinya dusta dan kepalsuan, maka orang Kristen harus waspada dan bijak dalam mendengarkan kontennya. Waspadalah terhadap nabi-nabi palsu dan segala pengajarannya. Namun di pihak lain, melalui media sosial, Berita Injil lebih luas dikenal oleh banyak orang dalam waktu singkat di seluruh dunia. Hanya saja, apakah konten yang disampaikan sudah benar dan bersumber dari ajaran Alkitab? Di sinilah tanggung jawab dan keseriusan mempersiapkan diri untuk sungguh-sungguh belajar teologi yang benar supaya konten yang dibagikan di media sosial berkenan kepada Allah, Bapa yang Mahakudus.

\section{Bahasa menurut Kisah Besar Alkitab}

Alkitab adalah firman Tuhan yang diwahyukan Allah secara khusus kepada para penulis yaitu orang-orang pilihan-Nya, secara verbal (tertulis) dalam bahasa manusia. Manusia dapat membaca Alkitab dalam bahasanya sendiri. Karena Allah menghendaki manusia mengenal diri-Nya dan karya-Nya dengan benar utuh dan lengkap. Di dalam Alkitab ada empat kisah besar yang menggambarkan keseluruhan rencana dan rancangan Allah khususnya dalam penebusan umat-Nya. Keempat kisah tersebut ditulis dengan menggunakan bahasa yang dapat dimengerti manusia, baik di zaman penulisan kitab dan sampai saat ini melalui berbagai terjemahan. Terjemahan Alkitab bernilai dan berharga bagi umat Allah di seluruh dunia, yang ada di dalam setiap suku bangsa. Tanpa Alkitab, umat Allah sangat sukar mengetahui dan mengenal Allah yang beranugerah dan mengasihinya.

Kisah besar di dalam Alkitab tersebut dituliskan secara kronologis, melintasi sejarah manusia, sejarah bangsa-bangsa dan khususnya sejarah umat Allah. Di dalam kisah-kisah yang kronologis itu ada kairos-kairos utama yang menggambarkan keunikan dari setiap kisah besar Alkitab. Kisah-kisah tersebut dituliskan diwahyukan Allah secara khusus dan hanya dapat dimengerti secara khususnya oleh orang-orang percaya. Surat Ibrani 1:1-3 menjelaskan kepada pembacanya bahwa Allah telah berulangkali berbicara kepada umat-Nya dalam berbagai cara, melalui para nabi dan puncaknya melalui AnakNya yang tunggal, Pengantara dan Penebus satu-satunya. Model komunikasi seperti ini dapat diterapkan dalam pemberitaan Injil, dimana orang Kristen berbicara dalam berbagai cara, termasuk melalui media sosial, untuk menyatakan rencana kehendak penebusan-Nya bagi umat-Nya di seluruh dunia. 


\section{Bahasa dalam Kisah Penciptaan Allah}

Allah menciptakan segala sesuatu dari tidak ada menjadi ada melalui firmanNya. Firman itu dapat dikenal secara Pribadi sebagai Logos dan juga secara impersonal sebagai kata (logos). Logos sebagai Mediator penciptaan dan yang dinyatakan-Nya untuk menciptakan segala sesuatu dari tidak ada menjadi ada. Allah menciptakan segala sesuatu melalui Logos dan dengan logos-Nya di dalam naungan Roh-Nya (Kej.1:1-2), di mana keberadaan Logos (Firman) dan logos (kata-kata-Nya) juga turut menopang, menjaga, memelihara dan menebus seluruh karya-Nya. Kata-kata Logos memiliki otoritas atas keberadaan segala sesuatu. Kemahakuasaan perintah Allah (firman Tuhan, kata-kata), yang olehnya Dia menjadikan segala sesuatu sebagaimana mereka ada, adalah sama pada permulaan penciptaan dan di sepanjang waktu dalam sejarah ciptaan. ${ }^{13}$

Menurut W. Andrew Hoffecker, "Hanya dengan menerima bahwa Allah ada dan telah secara otoritatif menyatakan diri-Nya kepada kita, barulah kita dapat naik melampaui opini semata dan mencapai suatu derajat kepastian (Hoffecker, 2006:209)." David Naugle menguraikan pemikirannya dengan mengatakan bahwa:

Ciri-ciri yang menentukan pribadi sebagai orang yang memiliki logos adalah kemampuan menggunakan satu hal untuk menggunakan hal lain (aliquid stans pro aliquo), untuk memilah satu bagian realitas dan menggunakannya untuk mengacu, mengartikan, atau mewakili bagian realitas lain. Yang paling khas, manusia menggunakan bunyi di dalam bentuk ucapan bahasa untuk memberi arti pada pemikiran-pemikiran, perasaan-perasaan, dan ide-ide serta orangorang, tempat-tempat dan hal-hal di dunia. ${ }^{14}$

Allah adalah Allah yang menyatakan diri-Nya, baik pada diri-Nya dan juga pada seluruh karya-Nya. Allah menyatakan diri-Nya secara umum melalui karya ciptaan-Nya untuk manusia mengetahui keberadaan-Nya dan secara khusus melalui firman-Nya dan Anak-Nya yang tunggal untuk manusia (umat pilihan) mengenal-Nya secara pribadi. Penyataan Allah dikomunikasikan secara non-verbal melalui alam semesta, tanpa katakata (Mzm.19:1-7), sedangkan secara verbal dituliskan dengan kata-kata manusia melalui inspirasi Roh Kudus kepada para penulis Alkitab dan secara personal dipresentasikan oleh Anak Allah yang tunggal melalui hidup dan kehidupan-Nya di bumi ini (Yoh.1:14; Ibr.1:1-3). Tanpa penyataan diri Allah, Ia tidak akan dikenal oleh manusia (Hoffecker, 2006:211). Demikian juga manusia sebagai gambar dan rupa Allah akan menyatakan dirinya kepada sesamanya agar saling mengenal satu sama lain. Manusia menyatakan dirinya dengan kehadirannya dan berbicara kepada sesama manusia.

${ }^{13}$ Albert M. Wolters, Pemulihan Ciptaan (Surabaya: Momentum, 2010), 18.

${ }^{14}$ Naugle, Wawasan Dunia, 359. 
Kebenaran Allah tersebut menyatakan diri-Nya dan dapat dijelaskan secara digital kepada segala bangsa, di mana media sosial saat ini dapat mengungkapkan dengan efektif ajaran-ajaran Alkitab secara publik dan universal sehingga pengguna media sosial dapat mengetahui dan mengenal Allah dengan baik dan benar.

Allah adalah Komunikator yang menciptakan manusia, di mana seseorang akan dapat berkomunikasi dengan diri-Nya dan sesama. Pesan yang dinyatakan Allah di dalam pewahyuan-Nya ialah keberadaan-Nya dan karya-Nya agar manusia kembali memiliki hubungan pribadi yang pernah putus hubungan dengan-Nya karena dosa (Yes.59:1-2). Metode dan model komunikasi ini penting dipelajari dengan cermat secara komprehensif agar makna pewahyuan Allah tercapai dengan sempurna kepada pengguna media sosial. David S. Dockery merumuskan makna dari pesan komunikasi dalam 5 tingkat, yaitu:

Meaning is created through a relational process that involves the interaction of communicators, massages, and channel on any of the following five levels: (1) Intrapersonal communication encompasses the meaning-making process at the deepest and most individual level where a communicator utilizes language or internal thought to foster understanding. Examples of intrapersonal communication include journaling, quiet times of private devotion, and prayer. (2) Interpersonal communication occurs when there are two communicators who, through the exchange of verbal and/or nonverbal messages, create new meaning. Interpersonal communication can be observed in any dyadic interaction (e.g., a conversation between a professor and student about a class project, a boy and a girl defining their relationship status, or even two colleagues preparing for an upcoming presentation. (3) Group communication describes the interactions among at least three individuals with a shared purpose. The size of the group may be as many as 12 or 13 , but to constitute a group each member must be able to communicate with all other members of the group. (4) Public communication occurs in a setting larger than a group and is characterized by predominantly one-way communication (i.e., a speaker delivering a message to an audience). At the public communication level, immediate interaction is generally limited to nonverbal feedback. (5) Finally, mass communication describes the transmission of messages from a communicator to very large audience and typically using mass media technologies (e.g., newspaper, radio, television, the Internet, etc.). ${ }^{15}$

15 David S. Dockery (Ed.), Faith and Learning: A handbook for Christian Higher Education (Nashville, Tennessee: G\&H Publishing Group, 2012), 327-328. 
Makna dari 5 tingkat di atas dinyatakan melalui kata-kata yang diucapkan atau disampaikan dari satu orang ke orang lain sebagai konten dalam media sosial. Kata-kata yang dimaksudkan itu bukan hanya berbentuk huruf tetapi simbol atau tanda yang memberikan gambaran tentang sesuatu obyek atau subyek yang sedang dan akan menjelaskan realitas. Makna dari konten pada dirinya dikomunikasikan melalui media sosial tetapi pengguna terbuka memaknainya menurut konteks masing-masing. Menurut Gorys Keraf, dalam tulisan Christina Purwanti, menjelaskan bahwa: "Manusia memakai bahasa dalam seluruh kesehariannya. Bahasa menjadi begitu penting dalam keseluruhan hidup manusia. Bahasa merupakan bunyi yang dihasilkan oleh alat ucap manusia yang merupakan simbol atau perlambang, yang memiliki tiga dimensi utama yakni dimensi masa lampau, masa sekarang, dan juga pada masa yang akan datang (Keraf, 1989)."16 Pemaknaan atas bahasa itu sebagai konten media sosial bukan hanya permasalahan teknis berkomunikasi, tetapi juga di dalam konten itu ada wawasan dunia yang berdampak langsung bagi pengguna media sosial. Karena itu orang Kristen harus menyadari bahwa konten media sosial penting mempertegas makna kehidupan dalam Wawasan Dunia Kristen, khususnya melalui pemberitaan Injil yang kontekstual.

Sekalipun setiap kata, simbol dan gambar tidak dapat sepenuhnya mewakili keberadaan dari esensi realitas dan isi hati manusia, tetapi setidaknya hal itu akan mendekati fakta dan kebenaran karena bahasa manusia tidak hanya disampaikan dalam bentuk lisan, tetapi juga tulisan, gambar dan lukisan. Manusia berusaha memahami dirinya yang diungkapkan melalui bahasanya dan pemahaman ini membutuhkan kedekatan pada obyek yang dipahaminya. F. Budi Hardiman menambahkan bahwa "Di dalam kehidupan sehari-hari kita berbicara dengan orang-orang lain. Memahami adalah proses menangkap maksud atau makna kata-kata yang diucapkan pembicara....... manusia tidak berpikir tentang hal yang sama, meski memakai kata yang sama."17 Pemaknaan ini akan dapat meningkatkan dorongan dari setiap orang untuk menemukan manfaat praktis dari obyek yang dimaknai untuk kehidupannya sehari-hari. Sebab itu Wawasan Dunia Kristen tidak hanya menyajikan pengajaran dan semangat kehidupan, juga memberikan contoh konkrit yang dapat dipraktikkan pengguna media sosial.

Alkitab menjadi bukti konkrit adanya kemampuan manusia membuat simbol, huruf, kata dan kalimat dari bahasa yang sudah ada menjadi bahasa yang baru dan perbaharui. Implikasi dari kemampuan ini, kelompok atau etnis di suatu lokasi atau tempat akan dapat menggunakan bahasa yang khas, unik dan menjadi identitas kelompok etnis tersebut. Keragaman bahasa antar etnis merupakan buah dari karya

16 Christina Purwanti (Juni 2020). EKSISTENSI BAHASA DALAM KOMUNIKASI INTERPERSONAL: SEBUAH PENDEKATAN INTERDISIPLINER [LANGUAGE EXISTENCE IN INTERPERSONAL COMMUNICATION: AN INTERDICIPLINARY APPROACH], Polyglot: Jurnal Ilmiah, Vol. 16 (2): 267, diakses dari https://ojs.uph.edu/index.php/PJI/article/view/2261/pdf., pada hari Senin, tanggal 31 Agustus 2020 pukul 15:17.

17 Hardiman, Seni Memahami, 31-32. 
Allah atas manusia, yang diciptakan menurut gambar dan rupa-Nya. Menurut Jonter Pandapotan Sitorus, "sifat kearbitreran bahasa itu yang menjadi sebab mendasar sehingga bahasa itu bervariasi. Hal itu pula yang memberi gambaran bahwa kita diciptakan tidak homogen, melainkan beranekaragam dengan keunikan-keunikannya masing-masing sebagai sebuah suku, adat, agama, bangsa dan negara."18 Media sosial membuka kesempatan bagi setiap orang mendengarkan kebenaran Injil melalui bahasa lokal atau bahasa nasional di mana ia tinggal dan berada. Pengguna media sosial bebas menegaskan kembali seluruh pengajaran Alkitab tanpa keraguan dengan kualitas konten yang teruji secara konkrit dalam konteks kekinian. Sebab itu penting melakukan kontekstualisasi kisah-kisah dari Alkitab ke dalam kehidupan konkrit pengguna media sosial. Hal tersebut berdampak luas untuk pembentukan peradaban umat manusia.

Alkitab terjemahan juga merupakan Kitab Suci dengan penggunaan bahasa yang dipakai manusia melintasi zaman dan suku bangsa dimana kisah-kisah yang ada di dalamnya tidak diganti atau disisipkan dengan kisah-kisah lain. Isi Alkitab sudah beku yang berarti setiap tulisan yang ada tidak dapat diubah sembarangan oleh siapa pun. ${ }^{19}$ Karena Alkitab adalah firman Tuhan yang dinafaskan-Nya seperti Allah memberikan nafas hidup kepada Adam. Namun kisah-kisah itu dikontekstualisasi dalam kehidupan saat ini. Makna dari kisah tidak diubah, relevansi dari kisah-kisah itu yang perlu diolah sebagai konten pemberitaan Injil melalui media sosial. Dengan demikian setiap orang Kristen akan menjalankan mandat Allah sebagai penatalayan-Nya dengan baik dan benar menurut ajaran Alkitab yang menghidupkan pengguna media sosial (Kej.1:27-28; $2: 15)$.

\section{Bahasa dalam Kisah Kejatuhan Manusia}

Allah menghendaki manusia berbicara dan bertutur kata dengan benar, baik, adil dan suci kepada-Nya dan kepada sesama dalam segala konteks kehidupan. Namun fakta dan informasi yang manusia nyatakan sejak kejatuhan dalam dosa, manusia sudah rusak total dan tidak mampu untuk menghasilkan berbagai pesan dan makna yang baik dan benar sehingga pesan dan arah kata-kata yang diucapkan tidak sesuai dengan kebenaran. Adam dan Hawa tidak setia pada firman Tuhan, menyalahkan pihak lain, dan tidak jujur kepada Allah. Kain dan kelompok pembuat menara Babel berkata dusta dengan sikap hati melawan Allah yang mengakibatkan kecelakaan atau kekacauan bagi sesama manusia (Kej. 4, 11). Menurut Louis Berkhof, Kerusakan total itu telah meluas ke seluruh bagian natur manusia, keseluruhan elemen penyusun, baik tubuh maupun jiwa; dan tidak ada kebaikan rohaniah, yaitu kebaikan dalam hubungan dengan Tuhan dalam

18 Jonter Pandapotan Sitorus (2018). RAGAM BAHASA DALAM PERSPEKTIF ALKITAB [LANGUAGE VARIETY FROM A BIBLICAL PERSPECTIVE], Polyglot: Jurnal Ilmiah, Vol.14 (2): 140, diakses dari https://ojs.uph.edu/index.php/PJI/article/view/809/pdf_1., pada hari Senin, tanggal 07 September 2020 pukul 20:32.

19 J.P. Sitorus (2018). RAGAM BAHASA, 142. 
diri orang berdosa sama sekali.20 Albert M. Wolter menegaskan bahwa "manusia sebagian besar telah kehilangan kemampuan menafsirkan apa yang dikatakan langit dalam pesan mereka yang tanpa kata tersebut. ${ }^{21}$ " Manusia berdosa kehilangan arah dan struktur dalam berbicara kepada Allah dan kepada sesama manusia. Ketika kita melihat dan membaca konten di media sosial, kita akan tahu bahwa manusia sudah mengalami kerusakan total.

Dosa telah merusak arti dan fungsi dari bahasa manusia. Kata-kata manusia berdosa berasal dari perbendaharaan hatinya yang diisi dari berbagai pengetahuan yang rasional, empiris, intuisi, dan berotoritas yang sudah dicemari dosa. Dosa telah mencemari akal budi, pengalaman, intuisi dan otoritas manusia sehingga pengetahuan akan kebenaran yang ada di dalam alam semesta, Alkitab dan pada Anak Allah telah salah arah, strukturnya pun rusak dan tidak bermakna bagi hidupnya. Dengan demikian, kata-kata yang digunakan orang berdosa secara lisan dan tertulis adalah dusta, tipu daya, cemar dan melawan Allah bahkan orang berdosa telah banyak menghasilkan informasi atau pesan yang tidak benar (hoax), keliru dan menyesatkan melalui media sosial. Manusia oleh naturnya (berdosa) telah memiliki keinginan yang tak dapat ditahan untuk senantiasa membelok ke arah yang jahat. Manusia tidak lagi dapat memilih dan melakukan apa yang baik dan benar. ${ }^{22}$

Sekalipun ada kemungkinan bahwa kata-kata yang disampaikan dan dijelaskan seseorang adalah benar, tetapi arah dan motivasi serta makna dari kata-kata itu dapat berbeda dan menyebabkan adanya ketidaksesuaian maksudnya untuk kebajikan manusia. Dosa telah menyebabkan arah dari setiap kata-kata manusia tidak lagi ditujukan kepada Allah dan tidak lagi untuk memuliakan-Nya. Tuhan berfirman bahwa "menurut ucapan engkau dibenarkan dan menurut ucapan engkau dihukum (Mat.12:37)" merupakan indikasi bahwa kata-kata menusia dapat berada di dalam ketidakbenaran. Memang benar ada anugerah umum dari Allah yang mencegah atau menahan kejahatan sehingga di dalam keadaan berdosa sekalipun, seseorang masih dapat berkata-kata dengan benar dan baik serta bijaksana. Hal ini dapat ditemukan dalam filsafat, budaya, dan peradaban manusia, baik di Barat dan Timur. Namun hal tersebut tidak dapat menghapuskan dusta dan kesesatan yang ada di dalam upaya baik manusia. Orang-orang seperti itu dilatih dan dididik untuk mengembangkan pengetahuan yang diperolehnya menjadi ukuran untuk menilai sesuatu realitas secara logis, valid dan komprehensif. Namun arah dari struktur kebenaran-kebenaran tersebut sudah menyimpang dan tidak tepat sasaran.

Di tengah-tengah kehidupan komunitas dan masyarakat yang plural, berita hoax semakin marak dinyatakan oleh orang-orang yang tidak memiliki pemikiran yang benar,

\footnotetext{
20 Louis Berkhof, Teologi Sistematika: Doktrin Manusia (Jakarta: Momentum, 2009), 145.

21 Wolters, Pemulihan Ciptaan, 47.

22 Berkhof, Doktrin Manusia, 149.
} 
tidak bersikap baik dan tidak suci, serta kurang bijaksana dalam penempatannya. Secara umum, etika atau tata krama dalam berbicara dan berkomunikasi dengan sesama hanya sebagai pengetahuan kognitif tanpa mengubah watak atau perilaku penggunanya. Itulah kondisi orang berdosa di dalam dunia berdosa yang mencemari seluruh aspek komunikasi manusia. Kejahatan moral merupakan hasil dari pilihan-pilihan dan tindakan-tindakan manusia. ${ }^{23}$ Pilihan dan tindakan manusia dalam berkomunikasi dengan kata dan gambar atau simbol tersebut ternyata sudah dicemari dosa sehingga menghasilkan kejahatan moral yang juga mencemari banyak orang. Saat ini media sosial telah menjadi sarana provokasi tindakan kejahatan yang mudah ditiru oleh siapa saja dan di mana saja. Kejatuhan manusia semakin masif dan mencemaskan kemajuan peradaban.

Menurut Nursyirwan Effendi, "Gerakan mempertahankan mainstream middle range theoris...mengalami pergeseran kepada konstruksi massal dari body of knowledge yang bersifat arbitrer dan berbasis virtual, khususnya melalui kehadiran berbagai media online."24 Pergeseran bukan saja pada sarana dan prasarana untuk menyampaikan pengetahuan, tetapi juga pada isi dan keutuhan dari berita atau pesan yang disampaikan di ruang publik sehingga pihak penerima pesan atau informasi tidak lagi memiliki keutuhan dari narasi yang dipresentasikan melalui media online tersebut sehingga isi dan pesan asli sudah diganti dengan yang lain. Hal ini sudah dimulai sejak "ular" di Taman Eden yang berbicara kepada Adam dan Hawa tentang firman Tuhan, di mana "ular" memutarbalik kebenaran yang asli dengan dusta yang seolah-olah adalah benar (Kej.3:1-3). Manusia jatuh karena kata-kata Iblis yang menyesatkan dan merusak pikiran manusia, sementara manusia menerimanya sampai ke lubuk hatinya sehingga mengubah wawasan dunianya terhadap Allah dan firman-Nya. Konten-konten di media sosial cenderung menampilkan prinsip wawasan dunia yang bertentangan dengan Allah dan ajaran Alkitab.

\section{Bahasa dalam Kisah Penebusan Kristus}

Alkitab sebagai sumber dan fondasi dari Wawasan dunia Kristen, menjelaskan dan mengarahkan kebutuhan manusia berdosa akan pengampunan, penebusan dan beberapa penekanan bahwa berkat keselamatan bisa terjadi karena kematian dan kebangkitan Kristus. ${ }^{25}$ Karya penebusan Kristus tidak hanya menebus umat-Nya yang berdosa dan memperdamaikan relasi dengan Allah tetapi juga menebus seluruh aspek kehidupan manusia, termasuk di dalam bahasa. Setiap konten pengguna media sosial seharusnya bersifat menebus budaya, sosial, dan kehidupan orang lain atau pengguna

23 Nash, Iman, 274.

24 Ignas Kleden \& Taufik Abdullah, Paradigma Ilmu Pengetahuan dan Penelitian Ilmu-ilmu Sosial dan Humaniora di Indonesia (Jakarta: LIPI, 2017), 302.

${ }^{25}$ Nash, Iman, 68. 
sosial lainnya sehingga dampak prinsip Wawasan Dunia Kristen bisa dilaksanakan secara konkrit.

Setiap hari kita berhadapan dengan orang lain untuk menyampaikan kata-kata tertulis, lisan dan gambar kepada orang lain atau sebaliknya menerima pengetahuan, informasi dan data dari orang lain. Dalam kondisi seperti itu, orang Kristen memiliki tanggung jawab untuk menebus kata-kata dan relasi yang semula tercemar dosa, ada kebohongan dan kemunafikan ke dalam kebenaran, kebaikan dan kesucian. Kita tidak hanya mengetahui kata-kata penulis kitab-kitab dalam Alkitab, latar belakang pendidikan dan kisah hidupnya, melainkan juga keadaan sosial, ekonomi, politis serta adat istiadat masyarakat dan pembaca mula-mula (jemaat penerima kitab). ${ }^{26}$ Hal ini penting agar orang Kristen memahami isinya dan menyampaikan kebenaran Injil lebih kontekstual dan lebih relevan bagi zamannya.

Setiap orang, termasuk orang-orang yang ada di dunia akademis, khususnya di dalam proses belajar dan mengajar, maka kita perlu merekonstruksi dan merestorasi isi pembicaraan dengan arah yang benar, adil, suci serta maknanya dapat diterapkan setiap hari oleh dosen dan mahasiswa. Penebusan ini bukan hanya berkaitan dengan hidup kekal melainkan berkaitan dengan cara dan gaya hidup dari orang percaya yang berbeda dengan orang dunia (1 Yoh.2:15-17). Sekalipun ada peperangan kata-kata, konsep dan prinsip di dalam pikiran dan relasi sosial akademis dengan berbagai pengetahuan yang ada, orang Kristen tetap memiliki keyakinan, pengetahuan dan pengalaman yang bersumber dari Allah dan firman-Nya dan seluruh kebenaran Allah yang ada di alam semesta ini. Selain itu, orang Kristen selalu berjuang menebus bahasa yang digunakan menurut wawasan dunia Kristen untuk menerangi kegelapan dari dunia ini. Rasul Paulus menegaskan kepada jemaat di Roma untuk secara aktif melakukan pembaharuan akal budi melalui penemuan kebenaran-kebenaran Allah yang non-verbal dan verbal agar orang percaya berada di dalam kehendak Allah (Rm.12:2). Menurut Douglas Groothuis:

Orang-orang yang mengikuti Kristus, yang adalah Kebenaran (Yoh.14:6), jangan sampai pernah merasa kebenaran memang sudah semestinya demikian, merasa puas dengan sedikit bantuan darinya, menolak untuk menguji klaim-klaim kebenaran mereka dengan realitas objektif atau gagal untuk menerapkan implikasi-implikasi dari kepercayaan mereka di dalam keseluruhan hidup mereka. ${ }^{27}$

${ }^{26}$ Paraphrase dari tulisan F. Budi Hardiman dalam buku Seni Memahami, 47.

27 Douglas Groothuis, Pudarnya Kebenaran: Membela Kekristenan terhadap Tantangan Postmodernisme (Jakarta: Momentum, 2003), 272. 
Penebusan bahasa ini bukan hanya mencakup pada diri, dari komunikator dan pesan yang disampaikan kepada komunikan, tetapi juga mencakup pada isi, arah dan strukturnya. Karena itu perbendaharaan kata-kata yang tersimpan di dalam hati (pikiran) yang terekam di dalam otak (tubuh) menjadi satu kesatuan yang sinkron dan tidak terpisahkan. Dengan jalan demikian setiap kata-kata itu dipertanggung jawabkan di hadapan Allah dan manusia. Yakobus mengingatkan orang Kristen supaya tidak memiliki sumber kata-kata yang tidak benar sehingga kata-kata orang Kristen itu sungguh-sungguh memuliakan Allah sejati, membangun rohani, serta memajukan peradaban umat manusia. Hal tersebut dapat dilakukan melalui konten yang baik dan benar di media sosial yang digunakan orang Kristen. Kita tidak perlu merasa malu atau ragu menuliskan hal yang berguna bagi sesama untuk memperkenalkan Injil.

Pilihan kata-kata, gambar dan desain, simbol sebagai sarana atau media di dalam berkomunikasi merupakan langkah awal sebelum seseorang menyampaikan berbagai informasi dan pengetahuannya bagi orang lain. Pilihan kata yang benar, baik, suci dan tepat akan terjadi bagi orang-orang Kristen yang tekun membaca, memikirkan dan merefleksi kebenaran-kebenaran Allah, yang sudah disistematiskan di dalam berbagai disiplin ilmu pengetahuan serta diwujudkan dalam berbagai artefak budaya. Kedua bagian tersebut perlu dilatih, dikembangkan dan dijadikan gaya hidup dari orang Kristen dalam mengunggah konten atau menulis status di media sosial yang digunakannya.

Firman Tuhan berkuasa mengubah hati manusia dan memerdekakan manusia dari perbudakan dosa dan dusta si jahat. Firman Tuhan bukan hanya pengetahuan kebenaran, tetapi juga kekuatan yang meruntuhkan wawasan dunia yang tidak benar. Karena itu, kesatuan pengetahuan (body of knowledge) berperan sebagai bagian representasi dari proses metafisis terhadap pengamatan realitas sosial, di mana firman Tuhan mewakili wawasan dunia Kristen dalam seluruh elemen dan keunikan kisah. ${ }^{28}$ Roh Kudus yang memberikan pencerahan kepada setiap orang untuk mengerti maksud dan tujuan firman Tuhan yang sudah diberitakan, termasuk melalui media sosial pada saat ini.

Hal penting yang perlu diperhatikan oleh orang percaya dalam melaksanakan proses berkomunikasi atau berbicara kepada orang lain di dunia ini, seperti yang dijelaskan oleh Tim Muehloff \& Todd V. Lewis sebagai berikut:

...public entertainment or virtually any communicative encounter as consisting of five distinct elements. Act is the artifact itself: the speech, the film, the event. Agent is the primary communicator of the artifact, the actor, the leader. Agency is the channel or mediated means to share the act: public presentation, filmed or

${ }^{28}$ Ignas Kleden \& Taufik Abdullah, Paradigma, 302. 
televised presentation, interpersonal communication. Scene identifies the historical context for the act and perhaps also identifies elements as descriptions of the immediate or universal audiences. Purpose describes the message intent as the rhetorical critical understand it. I have described the five elements of the pentad; what the rhetorical critic must do is provide reasoned and arguably supportable notions of each element to offer evaluation, which can then serve as a beginning for discussion and debate. ${ }^{29}$

Sebagai orang percaya yang dikaruniakan kuasa oleh Allah untuk memberitakan Kabar Baik dan kebenaran-kebenaran Allah, kita perlu memperhatikan perbedaan elemen-elemen dalam berkomunikasi dan mengisinya dengan prinsip wawasan dunia Kristen. Dengan demikian, "christian communicators provide alternative perspectives not only to the issues of pop culture but to those being debated in the university. Communication scholars call those providing alternative perspectives 'counterpublics." 30

Alkitab di sepanjang zaman mengajarkan bahwa panggilan utama semua orang Kristen adalah mengasihi Allah dengan segenap hatinya, memberikan teladan kebaikan di dalam Roh Kudus dan menaati perintah-perintah Allah. Dalam konteks bahasa artinya: pertama, panggilan Kristen tidak mengizinkan adanya pemisahan antara yang sekuler dan yang kudus; kedua, penemuan akan panggilan khusus yang fokus pada (1) apa yang menjadi bidang keahliannya, (2) apa yang perlu dilakukan bagi kebaikan semua orang dan (3) apa yang memberikan kepada orang tersebut kepuasan dan makna yang mendalam. ${ }^{31}$

Ketiga fokus tersebut akan mendorong orang Kristen untuk belajar dari Tuhan dalam menjalankan misi-Nya di bumi ini, karena Tuhan membuat terobosan-terobosan baru untuk menembus dinding pemisah yang seringkali membuat kita tercengang. ${ }^{32}$ Tuhan berbicara secara langsung kepada Zakheus (pemungut pajak), Nikodemus (tokoh agama), perempuan Samaria (beda gender dan beda suku bangsa), dan bahkan kepada penjahat yang di salib di bukit Golgota. Tuhan tidak membeda-bedakan kepada siapa Ia berbicara tentang Injil-Nya. Demikian juga seharusnya orang Kristen mengikuti model pemberitaan Injil yang sudah Tuhan contohkan untuk berbicara kepada semua orang tanpa diskriminasi. Orang Kristen dapat langsung berbicara kepada semua orang, dari yang paling tidak layak sampai yang paling terhormat dengan tutur kata dan bahasa yang membawa shalom dan Kabar Baik bagi pendengarnya.

29 Tim Muehlhoff \& Todd V. Lewis, Authentic Communication: Christian speech engaging culture (Downers Grove, Illinois: IVP Academic, 2010), 134.

30 Ibid., 145.

31 Douglas Groothuis, Pudarnya, 284-288.

32 Will Metzger, Beritakanlah Kebenaran (Surabaya: Momentum, 2005), 221. 
Karya penebusan melalui bahasa hanya dapat dimulai dari Allah yang membenarkan orang berdosa, yang diperdamaikan-Nya melalui dan di dalam Tuhan Yesus Kristus. Prinsip ini mengarahkan dan membimbing setiap orang Kristen untuk meningkatkan kualitas berpikir, berelasi dan berfungsi dalam berbicara tentang Injil dan kebenaran-kebenaran Allah. Samuel James menegaskan hal itu dengan pemikirannya,

According to Scripture, neither you nor I are the final interpreters of our own experience. Rather, we are finite creatures with limited vision. Our experiences certainly matter, but they are not ultimate. Rather than exalting our experiences to control what we will (or will not) believe about ultimate reality, we should let the revealed truth of God's word help us interpret our own experiences, and recenter our own story on the Grand Story. Doing this doesn't diminish our personhood or make us helpless to fight injustice or protect the vulnerable. Rather, it makes wisdom available to all who will come in faith to sit at the feet of the risen Christ, not merely those who have the highest number of compelling stories. $^{33}$

Pengetahuan kebenaran Injil yang dikaruniakan Allah akan memperlengkapi orang Kristen untuk memiliki makna dan tujuan hidup, memuliakan Allah dan menikmati-Nya melalui firman Tuhan yang diucapkan atau ditulis. Konteks zaman digital ini, bahasa yang benar, adil dan suci itu penting dan perlu ditampilkan di publik dengan kata-kata, pesan, dan gambar yang menerapkan prinsip penebusan. Orang Kristen tidak boleh diam dalam zaman online ini, karena ada banyak kebohongan, dusta dan tipu daya yang sudah tampil lebih dulu dengan kata-kata yang merusak, menyesatkan dan mencemarkan umat manusia. Oleh sebab itu, media harus diperiksa untuk menentukan natur, fungsi dan strukturnya. ${ }^{34}$ Orang Kristen harus hadir dan berjuang sebagai agen-agen transformasi peradaban melalui penebusan Kristus dengan memanfaatkan digital online yakni media sosial dengan berbagai aplikasi teknologinya saat ini.

\section{Bahasa dalam Kisah Penyempurnaan}

Beritakanlah Kabar Baik bagi segala makhluk sesuai konteks zaman, konteks budaya dan konteks penerimanya! Kalimat tersebut merupakan seruan etis dan sekaligus epistemologis bagi setiap orang Kristen agar setia mengabarkan Kabar Baik dengan benar dan bijaksana. Oleh karena itu, setiap orang Kristen perlu dan penting memiliki wawasan dunia Kristen yang komprehensif dari seluruh warisan iman sepanjang sejarah umat Tuhan dan mengembangkannya dalam kekinian. Dengan

${ }^{33}$ Samuel James, Constantly (Dis)connected.
${ }^{34}$ Douglas Groothuis, Pudarnya, 290-291 
demikian, menurut Tim dan Todd, "making our beliefs plausible will happen through taking time to understand the theoretical insights of others and offering insightful and respectful critique.35 Media sosial dapat digunakan sebagai media mendidik, mentransformasi pemikiran, dan mengubah karakter secara kritis yang terbuka kepada publik yang jejak digitalnya tersimpan dengan baik.

Dalam rangka mengkomunikasikan kebenaran-kebenaran Allah secara individu atau publik, orang Kristen perlu encouragement, intellectual preparation, and prayer. Encouragement diperlukan orang Kristen di dalam komunitas Kristen untuk membentuk karakter ilahi dan latihan memilih kata-kata yang tepat dalam berkomunikasi dengan pihak lain sebagai kesaksian. Intellectual preparation merupakan kekuatan yang berotoritas untuk menjelaskan kebenaran secara logis, valid, dan komprehensif di mana setiap orang Kristen tidak pernah berhenti untuk belajar dan mengisi hati dengan pemikiran-pemikiran yang inovatif, kreatif, dan energik. Prayer merupakan api bagi setiap orang Kristen untuk mempersiapkan diri sebagai komunikator yang handal, lihai, dan kreatif dalam menyampaikan pesan kepada orang lain. Keempat hal itu melatih dan mengevaluasi wawasan dunia orang Kristen agar sungguh-sungguh memiliki wawasan dunia Kristen yang berbasiskan Alkitab, berpusatkan Kristus dan bersandar pada Allah yang berdaulat atas segala sesuatu.

Akhirnya umat Tuhan akan berkata-kata, memuji dan memuliakan Allah untuk selamanya di langit dan bumi yang baru secara sempurna. Di bumi yang baru tidak akan ada lagi perbendaharaan kata yang sia-sia, cemar, dusta, najis dan buruk di hadapan Allah yang bertahta dan di antara umat-Nya. Karena itu, saat ini orang-orang Kristen adalah umat yang lebih dari pemenang dengan pengharapan kekal bahwa kata-kata mulia, benar, dan akan sungguh-sungguh dinikmatinya. Kesempurnaan atas umat pilihan-Nya akan nyata melalui puji-pujian kepada Allah Tritunggal bersama para malaikat untuk selama-lamanya melalui multi-bahasa yang sudah disempurnakan.

\section{Implikasi dalam Pemberitaan Injil melalui Media Sosial}

Implikasi teologis, wawasan dunia Kristen akan meningkatkan kualitas berpikir dan karakter yang saleh dalam pemberitaan Injil melalui media sosial karena ada pemberitaan injil lain yang bukan diajarkan Alkitab sehingga merusak fondasi iman dari para pembaca atau pendengarnya. Oleh karena itu, setiap kata dan kalimat yang ditulis serta dinyatakan secara publik melalui media sosial dipilih dengan benar agar Injil yang diberitakan sesuai dengan ajaran Alkitab, utuh dan benar. Setiap pengetahuan yang benar dan pengalaman yang suci penting dibuktikan obyektivitasnya secara korespondensi dan koherensi secara publik melalui media sosial sehingga setiap orang mengenal Injil yang benar. Selain itu, struktur kebenaran-kebenaran Injil dapat

35 Tim Muehlhoff \& Todd V. Lewis, Authentic Communication, 152. 
dijadikan tatanan moral dan arah bagi siapa saja untuk kemajuan peradaban sebab Tuhan Yesus tidak hanya menebus manusia berdosa, beroleh kesalamatan, Ia juga menebus kehidupannya.

Menurut Dave Raley, "Hari ini, konten yang berkualitas adalah raja, hal itu menjadi pokok kesuksesan Anda dalam menjangkau dan mempengaruhi orang pada media digital dan sosial. Kekristenan adalah kisah terbesar yang pernah diceritakan. Alkitab memberi kita konten tentang setiap isu terkait dengan kondisi manusia. Sebagai orang Kristen yang bijak dan kreatif, kita perlu berkomitmen untuk menciptakan dan membagikan konten penginjilan untuk ketiga tahap tadi: menabur, menuai dan memuridkan."36 Oleh karena itu, orang Kristen harus mempersiapkan diri untuk memiliki konten yang berkualitas sebelum memberitakan Injil melalui media sosial. Hal tersebut hanya ada pada diri orang Kristen yang sudah memiliki wawasan dunia Kristen yang komprehensif dan menerima pelatihan berbahasa yang baik dan benar. Saat ini kita dapat membuat konten teologis dan Injili dengan bebas melalui media sosial. Akan tetapi kita perlu memikirkan kualitas isinya dan momen yang tepat untuk meunggahnya agar hasilnya lebih efektif.

Segala kebenaran adalah kebenaran Allah seharusnya sejak dini setiap orang menerima pengetahuan yang benar, yang diperbincangkan di rumah, lalu diteruskan di sekolah atau kampus dan tempat bekerja. Hal ini berguna dalam proses pembentukan wawasan dunia Kristen. Dalam konteks saat ini, media sosial dapat digunakan sebagai sarana pembelajaran wawasan dunia Kristen, termasuk di dalamnya pemberitaan Injil untuk segala bangsa. Sebelum zaman digital ini, momen-momen penting dalam tindakan penebusan Allah dalam sejarah selalu diiringi dengan pewahyuan secara lisan. ${ }^{37} \mathrm{Hal}$ tersebut kemudian dilanjutkan dengan pemberitaan Injil secara tulisan dan juga menggunakan media cetak dan media elektronik (radio, televisi). Saat ini orang Kristen dapat melakukan pemberitaan Injil melalui media sosial yang bersifat global, secara langsung dan tidak langsung. Menurut Adrianus Pasasa bahwa:

Pada prinsipnya kemajuan teknologi informasi khususnya Internet memberikan suatu peluang untuk memberitakan Injil kepada siapa saja, karena internet tidak mengenal batas wilayah, agama, suku dan ras. Kehadiran teknologi informasi dapat dimanfaatkan untuk mentransformasi sarana dan metode penginjilan yang sudah berjalan selama ini, supaya semakin efektif lagi. ${ }^{38}$

\footnotetext{
36 Dave Raley (September 2017), Media?'s Role in the Gospel and Evangelism, diakses dari https://misi.sabda.org/peranan-media-dalam-injil-pemberitaannya, pada hari Kamis, tanggal 24 September 2020, pukul 14:16.

37 Metzger, Beritakanlah, 15.

38 Adrianus Pasasa (2015). Pemanfataan Media Internet Sebagai Media Pemberitaan Injil, Jurnal Simpson: Jurnal Teologi dan Pendidikan Agama Kristen, Vol 2, No 1: 76, diakses dari
} 
Implikasi penggunaan bahasa dalam pemberitaan Injil melalui media sosial mencakup pada pengetahuan akan Injil Yesus Kristus dan pengalaman hidup di dalam Tuhan secara terbuka dan tersimpan secara digital. Karena itu sikap dan tindakan dalam memanfaatkan media sosial dimulai dari pilihan kata yang tepat, benar, adil dan suci sehingga tidak menjadi batu sandungan. Dengan demikian setiap kata yang tidak benar dan tidak dapat dipertanggung jawabkan tidak lagi dituliskan atau disampaikan ke publik. Karena itu setiap kabar dusta dan informasi yang tidak membangun peradaban dan bertentangan dengan kehendak Allah haruslah disingkirkan dari media sosial.

Kesempatan memanfaatkan media sosial untuk pemberitaan Injil tidak disiasiakan dan penting dipersiapkan dengan baik, namun orang Kristen perlu menyadari kepentingan wawasan dunia Kristen melalui bahasa yang digunakan saat ini. Implikasi penggunaan bahasa di media sosial dibagi dalam hubungan vertikal dan horizontal. Jonter Pandapotan Sitorus menjelaskannya sebagai berikut:

Dalam hubungan vertikal, peranan bahasa memiliki andil yang sangat besar, yaitu sebagai cerminan diri kita kepada Allah. Hal itu berarti natur manusia seharusnya sangat berbeda dalam penggunaan bahasa manusia lainnya yang belum percaya kepada Allah. Dalam hubungan horizontal, peranan bahasa juga patut kita perhatikan. Sejauh ini peranan bahasa belum terlihat dengan baik. Masih adanya ucapan-ucapan yang tidak pantas diperdengarkan di depan publik baik kita sebagai pribadi maupun sebagai mahluk sosial. ${ }^{39}$

Hubungan vertikal berdampak pada hubungan horizontal secara langsung atau tidak. Namun kebiasaan kata-kata yang diungkapkan dalam hubungan vertikal akan muncul dalam hubungan horizontal yang dipublikasi melalui media sosial. Dengan demikian, setiap orang Kristen perlu melatih diri untuk meningkatkan kualitas berbahasa pada hubungan vertikal dan horizontal. Orang Kristen perlu memanfaatkan segala kebenaran Allah untuk mengisi hatinya agar memiliki arah dalam mengamati realitas secara inderawi, menghadapi pergumulan hidup, dan pengalaman berjalan bersama Allah. Kepentingan wawasan dunia Kristen tersebut akan berimplikasi mentransformasi kehidupan manusia melalui kesaksian hidup yang benar secara publik.

Implikasi dari prinsip tersebut dapat terwujud melalui bahasa yang dituliskan dan dibicarakan pada media sosial. Sejalan dengan hal itu, setiap pengalaman hidup seseorang di dalam kebenaran Allah dibicarakan dan diakomodasi orang lain untuk penerapan kebenaran yang bijaksana melalui bahasa dan maknanya berdasarkan ayat-

https://journal.sttsimpson.ac.id/index.php/Js/article/view/20/19 pada hari Kamis, tanggal 24 September 2020, pukul 15:52.

39 J.P. Sitorus, Bahasa, 91, 92. 
ayat Alkitab yang sudah direfleksikannya. ${ }^{40}$ Orang Kristen sebagai contoh dalam menggunakan bahasa yang benar, adil dan suci melalui media sosial yang digunakannya. Adrianus Pasasa menambahkan, "Seorang penginjil dapat memberikan informasi serinci mungkin tentang siapa Tuhan Yesus kepada orang lain. Mereka yang membacanya dan memiliki ketertarikan, kemudian membagikan informasi tersebut kepada orang lain. Begitu cepatnya informasi yang disampaikan oleh seorang penginjil, dan dalam hitungan detik informasi itu menyebar sampai kepada jutaan orang yang tersambung ke jejaring sosial." 41

Implikasi penginginjilan, Tuhan telah menyatakan perintah-Nya kepada para murid-Nya untuk pergi menjadikan segala bangsa murid-Nya dan menjadi saksi-Nya sampai ke ujung-ujung bumi. Perintah Tuhan sudah dilaksanakan murid-murid-Nya, dan sekarang orang Kristen berada pada zaman digital, sehingga perlu melaksanakan perintah Tuhan melalui media sosial tersebut. Karena media sosial menjangkau lebih banyak orang dan lebih cepat. Dalam konteks seperti itu, orang Kristen harus memanfaatkan kesempatan ini, karena setiap orang Kristen memiliki kemampuan bersaksi tersebut. Will Metzger berpendapat bahwa "Saya yakin kemampuan kita untuk bersaksi diawali dengan pandangan yang besar tentang Allah dan Yesus Kristus yang akan memberi orang-orang Kristen suatu dasar untuk merasa percaya diri, berpengharapan, dan nyaman dengan kemanusiaan mereka." 42

Di pihak lain, orang Kristen penting memperlengkapi diri dengan belajar berbagai ilmu pengetahuan yang berkualitas, pengalaman dan tradisi gereja yang baik dan suci untuk memperlengkapi diri agar siap sedia masuk ke dalam peperangan prinsip dengan wawasan dunia lainnya. Rasul Petrus mengingatkan orang Kristen harus siap sedia mempertanggung jawabkan imannya, diminta atau tidak diminta oleh orang lain (orang dunia). Karena itu pengajaran yang efektif harus menimbulkan di dalam diri orang percaya, rasa cinta kepada apa yang diajarkan dan hasrat untuk lebih mendalaminya. ${ }^{43}$

Impilikasinya orang Kristen harus bersedia mengevaluasi secara internal dan batiniah akan wawasan dunianya, serta menguji kesungguhan imannya secara rasional dan praktisnya sehingga wawasan dunia Kristen akan mengarahkan perbendaharaan kata-kata (bahasa) dengan kualitas dan kuantitas yang berdampak kekinian sampai kepada kekekalan. Hal ini penting bagi orang Kristen dalam pemberitaan Injil di media sosial agar berkualitas dan dapat dipertanggung jawabkan. Karena jejak digital tidak mudah dihapuskan atau dihilangkan setelah penggunanya mengunggah secara publik.

\footnotetext{
40 Paraphrase dari tulisan F. Budi Hardiman dalam buku Seni Memahami, 241.

41 Pasasa, Pemanfaatan Media Internet, 86.

42 Metzger, Beritakanlah, 219.

43 Anthony A. Hoekema, Manusia: Ciptaan Menurut Gambar Allah (Jakarta: Momentum, 2003),
}

289. 
Orang Kristen dipanggil oleh Allah dan diutus untuk menyampaikan Kabar Baik. Wawasan dunia Kristen memastikan bahwa orang Kristen dituntun untuk menyatakan karya penebusan Kristus dan saksi kebenaran pada setiap bidang kehidupan, dalam berbagai kesempatan yang ada pada komunitas media sosialnya. Berita, pesan, kata-kata dan kisah yang dituliskan dan dibicarakan di media sosial merupakan hasil dari berbagai pengetahuan yang benar, logis, valid dan komprehensif.

Kepentingan tersebut berimplikasi pada kemajuan peradaban manusia yang berotoritas dan kekuatan untuk mengalahkan segala tipu daya si jahat dan orang berdosa. Karena itu orang Kristen penting dilatih dan dipersiapkan untuk menyampaikan pesan, informasi dan gambar kepada orang lain melalui media sosial online saat ini (livestreaming) atau rekaman video. Justin Wise mengingatkan orang Kristen, "But not everyone will seize this opportunity. In fact, some churches will choose to stick their heads in the sand rather than face the changes head-on. History will show this dismissal as a fatal blow for local churches unwilling to adapt their methods of sharing the Gospel message." 44 Kesempatan zaman digital ini merupakan kesempatan yang harus ditanggapi dengan benar oleh setiap orang Kristen dan pengguna media sosial untuk semua generasi.

\section{Kesimpulan}

Wawasan dunia Kristen merupakan prinsip kehidupan bagi orang Kristen untuk melaksanakan mandat Allah di bumi ini, baik mandat Injil maupun mandat budaya. Salah satu bidang penting dalam kehidupan manusia ialah bahasa. Manusia dan keberadaannya di bumi dinyatakan dan dibuktikan melalui bahasa yang ada padanya. Di dalam bahasa yang sudah dikuduskan bagi Allah, setiap orang Kristen menerima dan mengajarkan keyakinan akan Allah yang benar, pengetahuan akan firman Tuhan dan pengalaman hidup yang saleh kepada sesama manusia. Kita harus bertemu dan berbicara dengan orang-orang dimana mereka berada dan kita harus mengenal Injil dengan cermat, khususnya pokok utama mengenai pembenaran oleh Kristus melalui iman semata-mata. ${ }^{45}$

Kelima elemen wawasan dunia yang diakomodasi ke dalam wawasan dunia Kristen merupakan strategi dan pembuktian yang bertanggung jawab untuk menegakkan prinsip dasar dari sistem kehidupan orang Kristen di dunia ini. Orang Kristen mampu mempertanggung jawabkan prinsip hidupnya dalam kehidupan seharihari berdasarkan pada seluruh ajaran Alkitab sepanjang zaman. Setiap orang Kristen dapat menunjukkan kepada orang-orang dunia bahwa kelima elemen wawasan dunia

${ }^{44}$ Justin Wise (February 2014), Social Media and Christian Ministry: Reaching the World for the Kingdom of God, diakses dari https://www.christianitytoday.com/edstetzer/2014/february/social-mediaand-christian-ministry-reaching-world-for-king.html, pada hari Kamis, 24 September 2020, pukul. 14:55.

45 Metzger, Beritakanlah, 228. 
Kristen itu solid dalam satu kesatuan yang komprehensif. Selanjutnya kelima elemen tersebut dielaborasi sedemikian kreatif dengan bahasa yang populer sebagai bagian dari model penginjilan melalui media sosial, baik yang dikerjakan secara individu maupun dikelola oleh lembaga-lembaga penginjilan, khususnya oleh gereja Tuhan di segala tempat.

Orang Kristen pun seharusnya memanfaatkan kisah-kisah besar di dalam Alkitab sebagai kisah Allah melalui sejarah alam semesta, sejarah manusia, dan sejarah umat Tuhan, khususnya kisah penebusan Kristus untuk pemberitaan Injil. Prinsip iman bahwa Allah yang disembah orang Kristen adalah Allah yang mutlak transenden dan Allah yang personal imanen mendorong orang Kristen untuk berani menyatakan pengenalan akan Allah ini melalui media sosial. Allah berbicara kepada manusia melalui karya-Nya, mujizat-Nya, para nabi, dan khususnya melalui Anak-Nya yang tunggal dengan bahasa yang dapat dimengerti manusia. Orang Kristen dipanggil Allah untuk berbicara kepada segala bangsa dan menjadikan segala bangsa murid Kristus melalui media sosial, di mana para pembaca dan pendengarnya melintasi segala tempat dan suku bangsa.

Allah telah menyatakan firman-Nya kepada manusia melalui kisah penciptaan, kejatuhan, penebusan dan sampai penyempurnaan di bumi yang baru secara lisan dan tertulis. Sekarang tibalah zamannya untuk orang Kristen berjuang menyampaikan Injil ke seluruh dunia melalui berbagai media sosial agar lebih efektif dan kreatif. Karena media sosial dapat menyampaikan berita Injil dengan jangkauan ke seluruh dunia dan segala bangsa dalam waktu yang singkat dan cepat.

\section{Referensi}

Berkhof, Louis. Teologi Sistematika: Doktrin Manusia. Jakarta: Momentum, 2009.

David S. Dockery (Ed.). Faith and Learning: A handbook for Christian Higher Education. Nashville, Tennessee: G\&H Publishing Group, 2012.

Groothuis, Douglas. Pudarnya Kebenaran: Membela Kekristenan terhadap Tantangan Postmodernisme. Jakarta: Momentum, 2003.

Hardiman, F. Budi. Seni Memahami: Hermeneutik dari Schleimacher sampai Derida. Yogyakarta: Kanisius, 2015.

Hoekema, Anthony A. Manusia: Ciptaan Menurut Gambar Allah. Jakarta: Momentum, 2003.

Kleden, Ignas \& Taufik Abdullah. Paradigma Ilmu Pengetahuan dan Penelitian Ilmu-ilmu Sosial dan Humaniora di Indonesia. Jakarta: LIPI, 2017.

Lewis, Todd V. \& Tim Muehlhoff. Authentic Communication: Christian Speech Engaging Culture. Downers Grove, Illinois: IVP Academic, 2010.

Metzger, Will. Beritakanlah Kebenaran. Surabaya: Momentum, 2005. 
Muehlhoff, Tim \& Todd V. Lewis. Authentic Communication: Christian speech engaging culture. Downers Grove, Illinois: IVP Academic, 2010.

Nash, Ronald H. Iman dan Akal Budi. Jakarta: Momentum, 2001.

Naugle, David K. Wawasan Dunia Sejarah Sebuah Konsep (Sebuah Pandangan Kristen). Surabaya: Momentum, 2010.

Sitorus, Jonter Pandapotan. Wawasan Dunia Kristen dan Dunia Ilmu Pengetahuan terhadap Bahasa. Malang: Evernity, 2018.

Turabian, Kate L. A Manual for Writers of Research Papers, Theses, and Dissertations, $7^{\text {th }}$ Edition. Chicago: Chicago Press, 2007.

Vyhmeister, Nancy Jean. Quality Research Papers: for students of religions and theology. Grand Rapids, Michigan: Zondervan, 2001.

Wolters, Albert M. Pemulihan Ciptaan. Surabaya: Momentum, 2010.

\section{Referensi Online}

James, Samuel (2019), Constantly (Dis)connected: How Online Habits Form Us, diakses pada hari Senin, tanggal 07 September 2020, dari https://www.desiringgod.org/ articles/constantly-disconnected.

Pasasa, Adrianus (2015). Pemanfataan Media Internet Sebagai Media Pemberitaan Injil, Jurnal Simpson: Jurnal Teologi dan Pendidikan Agama Kristen, Vol 2, No 1: 76, diakses pada hari Kamis, tanggal 24 September 2020, dari https://journal.sttsimpson.ac.id/index.php/Js/article/view/20/19.

Purwanti, Christina (Juni 2020). EKSISTENSI BAHASA DALAM KOMUNIKASI INTERPERSONAL: SEBUAH PENDEKATAN INTERDISIPLINER [LANGUAGE EXISTENCE IN INTERPERSONAL COMMUNICATION: AN INTERDICIPLINARY APPROACH], diakses pada hari Senin, tanggal 31 Agustus 2020, dari Polyglot: Jurnal Ilmiah V0l. 16 (2): 267, https://ojs.uph.edu/index.php/ $\mathrm{PJI} /$ article/view/2261/pdf.

Raley, Dave (September 2017), Media?'s Role in the Gospel and Evangelism, diakses pada hari Kamis, tanggal 24 September 2020, dari https://misi.sabda.org/perananmedia-dalam-injil-pemberitaannya.

Sitorus, Jonter Pandapotan (2018). RAGAM BAHASA DALAM PERSPEKTIF ALKITAB [LANGUAGE VARIETY FROM A BIBLICAL PERSPECTIVE], diakses pada hari Senin, tanggal 07 September 2020, dari Polyglot: Jurnal Ilmiah, Vol.14 (2): 140, diakses dari https://ojs.uph.edu/index.php/PJI/article/view/809/pdf_1

Wise, Justin (February 2014), Social Media and Christian Ministry: Reaching the World for the Kingdom of God, diakses pada hari Kamis, 24 September 2020, dari https://www.christianitytoday.com/edstetzer/2014/february/social-mediaand-christian-ministry-reaching-world-for-king.html. 